\title{
North Korea's way with weapons
}

\begin{abstract}
The deal between the United States and North Korea is not the climb-down it may appear, but should spur the nuclear powers to a comprehensive test-ban treaty before next year.
\end{abstract}

LAST week's agreement on nuclear weapons between the United States and North Korea is not the happiest agreement of its kind. The US administration's political opponents are muttering about the deal. The International Atomic Energy Agency (IAEA) in Vienna is uneasy at the prospect of the delay there will now be before it will have access to sites it wishes to inspect. There is even more general discontent that the example of North Korea will now become an illustration to the world's smallest powers of how to win important concessions from the United States: pretend to have a nuclear weapons programme, reject inspections under IAEA safeguards agreements and wait for an invitation to Geneva (where last week's deal was signed).

Luckily, that is not the whole truth, or even half of it. North Korea is a special case in at least three respects. First, it is an ex-client state of the ex-Soviet Union which is now out in the economic cold. (Economic production is actually falling, as in Cuba and other states in the same plight.) Second, North Korea is ethnically and culturally a part of the Korean peninsula, of which economically successful South Korea occupies the remainder. Third, the North Korean government is in the same fix as China some years ago: how can it follow the path of economic liberalism while preventing its own people from breaking the strict rules under which they live?

The concessions wrung from the United States last week, amounting to more open diplomatic recognition and the modification of the US trade embargo in force since the shooting stopped in the Korean War in 1953 (there is still no peace treaty), will not in themselves resolve those dilemmas. The most likely possibility is that South Korean companies will begin to invest in the north, but Pyongyang will be nervous that only the subversive dream of reunification can follow. And, of course, the suspicions are correct. Long before the two light-water reactors promised by the United States have been commissioned (against the promise not to extract plutonium from fuel already irradiated), it is more likely than not that North Korea will be a very different place.

Even so, the worry that the North Korean example will provoke other members of the Non-Proliferation Treaty (NPT) to follow suit is not unreal, although the most obvious analogies are inapplicable. Countries such as Cuba, for example, would not at this stage be able to launch even a credible rumour of nuclear intentions on the world. A more likely outcome is that, if the time should come for brokering an agreement between, say, India and Pakistan, they will join the NPT, the brokers will be faced with demands they cannot meet.

The lessons, for the nuclear powers, are straightforward. The most urgent need is that they should be prepared to disarm the mostly empty grumbling by non-nuclear states about the asymmetry of the NPT by finishing off the negotiation of a comprehensive test-ban treaty. With the NPT review conference due next April, there is not now much time left. The second lesson is that the other declared nuclear powers (there are four of them) should wring out of China a much more explicit declaration of its strategy in respect of nuclear weapons. There was a nuclear test (underground) in China on 7 October, but nobody is saying why.

\section{Who is Caesar's wife?}

Politicians accused of conflicts of interest may be a model for ethics in the research community.

As the research profession awakens to the potentially corrosive influence of external commercial interests within academic institutions, it must take some note of the charges of corruption now flying about in public life. Sadly, the election of a new government in Italy earlier this year has not banished long-standing anxiety about financial links between the government and those who seek to influence it. In Japan, the present government owes its place to the taint of influence-peddling its predecessor had acquired. In the United States, there is the usual trickle of fall-out from public office as people are alleged to have broken creditably strict rules. (Representative Dan Rostenkowski is the latest to be under a cloud.) Now the rot seems to have spread to France and Britain, where ministers have been compelled by the discovery of wrong-doing to give up their posts in recent weeks and days.

The cynical view that politicians are always and everywhere corrupt is a slander, but its wide currency is all too understandable and must, at least subliminally, help to shape the way that people elsewhere behave. But, superficially at least, a study of political behaviour would offer little help in guiding academic researchers through the conflicts of interest they will encounter. Politicians are usually caught out selling influence, sometimes for personal reward, often in their party's interest. (The British minister who quit last week was apparently paid $£ 2,000$ for asking a question in the 